\title{
ANALISIS FAKTOR-FAKTOR YANG MEMENGARUHI TINGKAT KEPATUHAN WAJIB PAJAK ORANG PRIBADI DI LINGKUNGAN KANTOR PELAYANAN PAJAK PRATAMA, TIGARAKSA TANGERANG
}

\author{
Maya Tantio Dharma; Stefanus Ariyanto \\ Accounting and Finance Department, Faculty of Economic and Comunication, BINUS University \\ Jln. K.H. Syahdan No 9, Palmerah, Jakarta Barat 11480 \\ sariyanto@binus.edu
}

\begin{abstract}
Tax collection is not an easy matter. Active participation from the tax authorities also requires the willingness of the taxpayer. A public reaction can be seen from the taxpayer's willingness to pay taxes. Willingness and awareness to pay taxes represent a value contributed by someone (which has been determined by regulation). Tax is used to finance public expenditures without any direct benefit. Taxpayer's awareness about taxation functions as state funding is needed to improve tax compliance and to determine the level of tax compliance in implementing their tax obligations. Limitation of the scope of this study is the effect of the level of awareness of paying taxes, taxpayer's understanding about tax benefits, tax penalties, and understanding of service quality to the tax authorities of individual taxpayer compliance in the fulfillment of tax obligations, as well as restricted to data obtained through questionnaires received and filled by the individual taxpayer of Tigaraksa Pratama Tax Office area. Data were obtained through questionnaire and processed and analyzed using parametric statistical tests and multiple linear regression with 4 independent variables and one dependent variable resulted in the conclusion that the factors that most influence taxpayer compliance in carrying out its tax liability is the use of sanctions against taxpayers who do not carry out its obligations under applicable legislation.
\end{abstract}

Keywords: Taxpayers, tax compliance, taxpayer ID

\begin{abstract}
ABSTRAK
Pemungutan pajak bukan perkara mudah. Di samping peran serta aktif dari aparat pajak, kemauan dari para Wajib Pajak juga dituntut. Salah satu bentuk reaksi masyarakat dapat dilihat dari kemauan Wajib Pajak untuk membayar pajak. Kemauan dan kesadaran membayar pajak menunjukkan suatu nilai rela dikontribusikan oleh seseorang (yang telah ditetapkan oleh peraturan) yang digunakan untuk membiayai pengeluaran umum negara dengan tidak mendapat kontribusi secara langsung. Kesadaran Wajib Pajak atas fungsi perpajakan sebagai pembiayaan negara sangat diperlukan untuk meningkatkan kepatuhan Wajib Pajak. Untuk mengetahui tingkat kepatuhan Wajib Pajak dalam melaksanakan kewajiban perpajakannya, batasan ruang lingkup dari penelitian ini adalah pengaruh tingkat kesadaran membayar pajak, pemahaman Wajib Pajak terhadap manfaat pajak, pemahaman tentang sanksi pajak, dan kualitas pelayanan fiskus terhadap kepatuhan Wajib Pajak Orang Pribadi dalam pemenuhan kewajiban perpajakannya. Selain itu, penelitian dibatasi pada data yang diperoleh melalui kuesioner yang diterima dan diisi oleh Wajib Pajak Orang Pribadi yang melakukan pekerjaan bebas di lingkungan Kantor Pelayanan Pajak Pratama, Tigaraksa. Data responden diperoleh melalui kuesioner dan diolah serta dianalisis menggunakan uji statistic parametric dan regresi linear berganda dengan 4 variabel bebas dan 1 variabel terikat menghasilkan simpulan bahwa faktor yang paling memengaruhi kepatuhan wajib pajak dalam melaksanakan kewajiban pajaknya adalah penggunaan sanksi terhadap wajib pajak yang tidak melaksanakan kewajibannya sesuai peraturan perundang-undangan yang berlaku.
\end{abstract}

Kata kunci: Wajib Pajak, kepatuhan, NPWP 


\section{PENDAHULUAN}

Pada saat ini penerimaan pajak merupakan komponen terbesar dari APBN dengan jumlah yang meningkat secara konsisten dari 2007 sampai dengan 2013, yang merupakan 60-70\% pendapatan negara (BPS, n.d.). Peningkatan jumlah realisasi penerimaan pajak dari tahun ke tahun ini tidak terlepas dari reformasi perpajakan yang dilakukan sejak 2007 dan berlanjut sampai sekarang. Hal ini menghasilkan peningkatan jumlah pemilik Nomor Pokok Wajib Pajak (NPWP). Meskipupun demikian, kepemilikan NPWP baru tidak serta merta memberikan kontribusi signifikan terhadap jumlah penerimaan pajak sebab tidak dibarengi dengan upaya sosialisasi kepada wajib pajak untuk melaksanakan kewajibannya untuk melapor dan menyetorkan pajak (sesuai sistem self assessment yang berlaku). Hal ini terutama terjadi pada wajib pajak orang pribadi yang sebagian besar merupakan karyawan (yang pajaknya dipotong oleh pemberi kerja) dan orang pribadi yang melakukan pekerjaan bebas yang didominasi oleh Usaha Mikro, Kecil, dan Menengah (UMKM).

Pemungutan pajak memang bukan perkara mudah. Di samping peran serta aktif dari aparat pajak, juga dituntut kemauan dari para Wajib Pajak itu sendiri. Salah satu bentuk reaksi masyarakat dapat dilihat dari kemauan Wajib Pajak untuk membayar pajaknya. Kemauan dan kesadaran membayar pajak menunjukkan suatu nilai yang rela dikontribusikan oleh seseorang (yang telah ditetapkan oleh peraturan) yang digunakan untuk membiayai pengeluaran umum negara dengan tidak mendapat kontribusi secara langsung. Kesadaran Wajib Pajak atas fungsi perpajakan sebagai pembiayaan negara sangat diperlukan untuk meningkatkan kepatuhan Wajib Pajak.

Secara sederhana, tingkat kepatuhan Wajib Pajak tercermin dalam persentase pelaporan Pajak Penghasilan Tahunan, SPT Tahunan, baik untuk Wajib Pajak Orang Pribadi maupun Wajib Pajak Badan. Berdasarkan data monitoring SPT Tahunan untuk tahun pajak 2010, Wajib Pajak yang melaporkan SPT Tahunan sebanyak 6.388.498 Wajib Pajak. Jumlah ini kemudian meningkat menjadi 9.891.120 pada 2011 dan untuk tahun pajak 2012 hingga 30 September 2013 sebanyak 9.921.066. Sementara itu, jumlah Wajib Pajak terdaftar yang wajib SPT per 31 Desember 2012 sebanyak 17.731.736 Wajib Pajak. Maka rasio 55,95\% untuk tingkat kepatuhan di tahun pajak 2012 belum dapat dikatakan tinggi jika melihat kembali SE-06/PJ/2012 tentang Target Rasio Kepatuhan Penyampaian SPT untuk Tahun Pajak 2012. Dalam surat edaran tersebut, Dirjen Pajak memberikan target rasio terendah sebesar 60 persen, ini pun hanya untuk wilayah Pulau Nusa Tenggara dan Papua (Hasan, 2013).

Penelitian terdahulu mengenai kepatuhan perpajakan telah dilakukan menunjukan bahwa kesadaran membayar pajak, pengetahuan, dan pemahaman tentang peraturan pajak serta norma moral secara parsial berpengaruh terhadap kemauan membayar pajak pada Wajib Pajak orang pribadi yang melakukan pekerjaan bebas. Persepsi yang baik atas efektivitas sistem perpajakan serta variabel tingkat kepercayaan terhadap sistem pemerintahan dan hukum secara parsial tidak berpengaruh terhadap kemuan membayar pajak pada Wajib Pajak orang pribadi yang melakukan pekerjaan bebas. Kemauan membayar pajak dipengaruhi oleh kesadaran membayar pajak, pengetahuan, dan pemahaman tentang peraturan pajak, persepsi yang baik atas efektivitas sistem perpajakan, tingkat kepercayaan terhadap sistem pemerintahan dan hukum serta norma moral memengaruhi variabel kemauan membayar pajak (Permadi, Nasir, \& Anisma 2013). Berdasarkan penelitian Hidayat dan Nugroho (2010) diperoleh simpulan bahwa sikap terhadap ketidakpatuhan berpengaruh negatif dan tidak signifikan terhadap niat untuk tidak patuh terhadap pajak. Kedua, norma subjektif berpengaruh positif dan tidak signifikan terhadap niat untuk tidak patuh terhadap pajak. Ketiga, kewajiban moral berpengaruh positif dan signifikan terhadap niat untuk tidak patuh terhadap pajak. Keempat, PBC berpengaruh negatif dan tidak signifikan terhadap niat untuk tidak patuh terhadap pajak. Kelima, PBC berpengaruh negatif dan tidak signifikan terhadap perilaku ketidakpatuhan pajak. Keenam, niat seseorang untuk tidak patuh terhadap pajak berpengaruh positif dan signifikan terhadap perilaku ketidakpatuhan pajak. 
Berdasarkan kondisi yang telah dipaparkan, maka dilakukan penelitian yang mengkaji tentang faktor-faktor yang memengaruhi tingkat kepatuhan Wajib Pajak dalam memenuhi kewajiban perpajakannya. Penelitian terhadap Wajib Pajak Orang Pribadi ini dilakukan di Kantor Pelayanan Pajak (KPP) Pratama Tigaraksa Tangerang. Untuk mengetahui tingkat kepatuhan Wajib Pajak dalam melaksanakan kewajiban perpajakannya, ruang lingkup dari penelitian ini dibatasi pada pengaruh tingkat kesadaran membayar pajak, pemahaman Wajib Pajak terhadap manfaat pajak, pemahaman tentang sanksi pajak, dan kualitas pelayanan fiskus terhadap kepatuhan Wajib Pajak Orang Pribadi dalam pemenuhan kewajiban perpajakannya, serta dibatasi pada data yang diperoleh melalui kuesioner yang diterima dan diisi oleh Wajib Pajak Orang Pribadi yang melakukan pekerjaan bebas di lingkungan Kantor Pelayanan Pajak Pratama Tigaraksa.

Tujuan yang ingin dicapai dalam penelitian ini adalah sebagai berikut. Pertama, menganalisis apakah tingkat kesadaran membayar pajak berpengaruh terhadap kepatuhan Wajib Pajak Orang Pribadi dalam memenuhi kewajiban perpajakan di Kantor Pelayanan Pajak Pratama Tigaraksa. Kedua, menganalisis apakah pemahaman yang dimiliki Wajib Pajak Orang Pribadi tentang manfaat pajak dapat berpengaruh terhadap kepatuhan wajib pajak orang pribadi dalam memenuhi kewajiban perpajakan di Kantor Pelayanan Pajak Pratama Tigaraksa. Ketiga, menganalisis apakah pemahaman yang dimiliki Wajib Pajak tentang sanksi pajak berpengaruh terhadap kepatuhan Wajib Pajak Orang Pribadi dalam memenuhi kewajiban perpajakan di Kantor Pelayanan Pajak Pratama Tigaraksa. Keempat, menganalisis apakah kualitas pelayanan fiskus berpengaruh terhadap kepatuhan Wajib Pajak Orang Pribadi dalam memenuhi kewajiban perpajakan di lingkungan Kantor Pelayanan Pajak Pratama Tigaraksa.

Manfaat yang diharapkan dari penelitian ini adalah sebagai berikut. Pertama, memberikan dasar pertimbangan mengenai upaya yang harus menjadi prioritas pemerintah dalam hal ini Dirjen Pajak untuk meningkatkan penerimaan pajak. Kedua, sebagai bahan tambahan pertimbangan dan pemikiran untuk penelitian lebih lanjut dalam bidang yang sama yaitu menyangkut faktor-faktor yang memengaruhi tingkat kepatuhan Wajib Pajak Orang Pribadi dalam melaksanakan kewajiban pajaknya. Ketiga, memberikan pemahaman yang lebih luas terutama kepada masyarakat yang belum sadar akan pentingnya membayar pajak dan manfaat atas membayar pajak guna meningkatkan kesejahteraan negara dan kesadaran dalam pemenuhan kewajiban perpajakan bagi masyarakat luas terutama Wajib Pajak.

\section{Landasan Teori}

\section{Sistem Pemungutan Pajak}

Sistem pemungutan pajak adalah sistem yang digunakan dalam mengenakan, menghitung, memungut, dan membayar pajak. Resmi (2011:11) membagi sistem pemungutan pajak menjadi tiga yaitu: official assessment system, self assessment system, witholding system. Official Assessment System adalah sistem pemungutan pajak yang memberi kewenangan aparatur perpajakan untuk menentukan sendiri jumlah pajak yang terutang setiap tahunnya sesuai dengan peraturan perundangundangan perpajakan yang berlaku. Dalam sistem ini, inisiatif serta kegiatan menghitung dan memungut pajak sepenuhnya berada di tangan para aparatur perpajakan. Dengan demikian, berhasil atau tidaknya pelaksanaan pemungutan pajak banyak bergantung pada aparatur perpajakan (peranan dominan ada pada aparatur perpajakan). Self Assessment System merupakan sistem pemungutan pajak yang memberi wewenang Wajib Pajak dalam menentukan sendiri jumlah pajak yang terutang setiap tahunnya sesuai dengan peraturan perundang-undangan perpajakan yang berlaku. Dalam sistem ini, inisiatif serta kegiatan menghitung dan memungut pajak sepenuhnya berada di tangan Wajib Pajak. Wajib Pajak dianggap mampu menghitung pajak, mampu memahami undang-undang perpajakan yang sedang berlaku, dan mempunyai kejujuran yang tinggi, serta menyadari akan arti pentingnya membayar pajak. Oleh karena itu, Wajib Pajak diberi kepercayaan untuk: menghitung sendiri pajak 
yang terutang; memperhitungkan sendiri pajak yang terutang; membayar sendiri jumlah pajak yang terutang; melaporkan sendiri jumlah pajak yang terutang; dan mempertanggungjawabkan pajak yang terutang. Witholding System adalah suatu sistem pemungutan pajak member wewenang kepada pihak ketiga untuk memotong atau memungut besarnya pajak yang terutang oleh Wajib Pajak.

\section{Batas Waktu Penyampaian Surat Pemberitahuan}

Sesuai pasal 3 ayat (3) Undang-Undang Nomor 28 Tahun 2007 tentang Ketentuan Umum dan Tata Cara Perpajakan yang diikuti dengan Peraturan Menteri Keuangan Nomor 80/PMK.03/2010 Tanggal 5 April 2010, batas waktu penyampaian SPT diatur: (1) untuk SPT Masa, paling lambat 20 (dua puluh) hari setelah masa pajak; (2) untuk SPT tahunan, paling lambat 3 (tiga) bulan setelah akhir tahun pajak. Pengaturan lainnya diperlakukan untuk PPh Pasal 22 Impor, Pajak Penghasilan Pasal 22 Bendaharawan dan SPT Masa Pajak Pertambahan Nilai yang disampaikan Direktur Jendral Bea Cukai.

\section{METODE}

Penelitian ini menganalisis kepatuhan Wajib Pajak Orang Pribadi beserta faktor-faktor yang memengaruhi di lingkungan Kantor Pelayanan Pajak Pratama Tigaraksa Tangerang. Karakteristik penelitian ini adalah sebagai berikut. Pertama, jenis penelitian ini adalah penelitian kuantitatif. Kedua, penelitian ini melibatkan banyak sampel. Ketiga, unit analisis adalah Wajib Pajak Orang Pribadi yang melakukan pekerjaan bebas di KPP Pratama Tigaraksa Tangerang. Keempat, lingkungan penelitian yaitu lingkungan riil. Kelima, jenis dan sumber data yang digunakan dalam penelitian ini adalah data primer dan sekunder.

\section{HASIL DAN PEMBAHASAN}

Data yang diolah dalam penelitian ini adalah jawaban responden atas kuesioner yang telah disebarkan. Penelitian ini dilakukan dengan mengambil populasi dari Kantor Pelayanan Pajak Pratama Tigaraksa Tangerang, yaitu Wajib Pajak Orang Pribadi dalam KPP tersebut. Data mengenai pendistribusian kuesioner dapat dilihat pada Tabel 1. Berikut ini merupakan jumlah kuesioner yang didistribusikan dan tingkat pengembaliannya. Sementara karakteristik responden dapat dilihat di Tabel 2 .

Tabel 1 Jumlah Sampel Penelitian

\begin{tabular}{lcc}
\hline \multicolumn{1}{c}{ Keterangan } & Jumlah & Persentase \\
\hline Jumlah kuesioner yang disebar & 115 & $100 \%$ \\
Kuesioner yang kembali & 109 & $94.78 \%$ \\
Kuesioner yang tidak dapat digunakan & 17 & $14.78 \%$ \\
Kuesioner yang dapat digunakan & 92 & $80 \%$ \\
\hline
\end{tabular}


Tabel 2 Karakteristik Responden

\begin{tabular}{|c|c|c|c|}
\hline Data Deskriptif & Keterangan & Jumlah & $\%$ \\
\hline \multirow{2}{*}{ Jenis Wajib Pajak } & Orang Pribadi & 92 & $100 \%$ \\
\hline & Badan & 0 & $0 \%$ \\
\hline \multirow{3}{*}{ Jenis Kelamin } & & 92 & $100 \%$ \\
\hline & Laki-Laki & 50 & $54.35 \%$ \\
\hline & Perempuan & 42 & $45.65 \%$ \\
\hline \multirow[t]{2}{*}{ Total } & & 92 & $100 \%$ \\
\hline & 21-30 tahun & 13 & $14.00 \%$ \\
\hline \multirow{3}{*}{ Usia } & $31-40$ tahun & 30 & $32.60 \%$ \\
\hline & $41-50$ tahun & 41 & $44.70 \%$ \\
\hline & $>50$ tahun & 8 & $8.70 \%$ \\
\hline \multirow{4}{*}{ Jenis Pekerjaan } & & 92 & $100 \%$ \\
\hline & Karyawan Swasta & 0 & $0 \%$ \\
\hline & Pegawai Negeri & 0 & $0 \%$ \\
\hline & Wiraswasta & 92 & $100 \%$ \\
\hline Total & & 92 & $100 \%$ \\
\hline
\end{tabular}

\section{Uji Asumsi Validitas dan Reliabilitas}

\section{Uji Validitas}

Dalam penelitian ini diketahui bahwa r-tabel adalah sebesar 0.17. Dengan demikian, dapat disimpulkan bahwa setiap pernyataan didalam kusioner yang berkaitan dengan variabel $\mathrm{X}_{1}$ atau tingkat kesadaran membayar pajak adalah valid dan dapat digunakan untuk penelitian karena $r$-hitung $>\mathrm{r}$ tabel.

Tabel 3 Uji Validitas $X_{1}$ (Tingkat Kesadaran Membayar Pajak)

Item-Total Statistics

\begin{tabular}{crrrr}
\hline & $\begin{array}{c}\text { Scale Mean if Item } \\
\text { Deleted }\end{array}$ & $\begin{array}{c}\text { Scale Variance if Item } \\
\text { Deleted }\end{array}$ & $\begin{array}{c}\text { Corrected Item- } \\
\text { Total Correlation }\end{array}$ & $\begin{array}{c}\text { Cronbach's Alpha if Item } \\
\text { Deleted }\end{array}$ \\
\hline P1 & 12.26 & 5.975 & .414 & .684 \\
P2 & 12.29 & 5.309 & .498 & .650 \\
P3 & 12.30 & 5.269 & .556 & .626 \\
P4 & 12.33 & 5.871 & .428 & .678 \\
P5 & 12.16 & 5.501 & .447 & .672 \\
\hline
\end{tabular}

Sumber: Data diolah oleh SPSS 20 
Berdasarkan hasil pengujian validitas atas variabel X2 diketahui r-tabel adalah 0.17. Suatu item pernyataan dikatakan valid jika r-hitung (Corrected Item-Total Correlation) $\geq$ r-tabel. Dengan demikian, dapat disimpulkan bahwa setiap pernyataan dalam kuesioner yang berkaitan dengan variabel $\mathrm{X}_{2}$ atau pemahaman Wajib Pajak terhadap manfaat pajak adalah valid dan dapat digunakan untuk penelitian karena r-hitung $>$ r-tabel.

Tabel 4 Uji Validitas $\mathrm{X}_{2}$ (Pemahaman Wajib Pajak Terhadap Manfaat Pajak) Item-Total Statistics

\begin{tabular}{cccrc}
\hline & $\begin{array}{c}\text { Scale } \\
\text { Mean if Item } \\
\text { Deleted }\end{array}$ & $\begin{array}{c}\text { Scale } \\
\text { Variance if Item } \\
\text { Deleted }\end{array}$ & $\begin{array}{c}\text { Corrected } \\
\text { Item-Total } \\
\text { Correlation }\end{array}$ & $\begin{array}{c}\text { Cronbach's } \\
\text { Alpha if Item Deleted }\end{array}$ \\
\hline P6 & 12.58 & 5.192 & .437 & .750 \\
P7 & 12.64 & 4.782 & .605 & .688 \\
P8 & 12.71 & 4.781 & .648 & .674 \\
P9 & 12.62 & 4.942 & .607 & .689 \\
P10 & 12.59 & 5.564 & .365 & .772 \\
\hline \multicolumn{5}{c}{ Sumber: Data diolah oleh SPSS 20 }
\end{tabular}

Hasil uji validitas terhadap variabel $\mathrm{X}_{3}$ atau pemahaman tentang sanksi adalah valid karena $\mathrm{r}$-hitung (Corrected Item-Total Correlation) > r-tabel (0.17) untuk setiap pernyataan yang ada dalam kuesioner.

Tabel 5 Uji Validitas X3 (Pemahaman Tentang Sanksi Pajak)

Item-Total Statistics

\begin{tabular}{lrrrr}
\hline & $\begin{array}{c}\text { Scale Mean } \\
\text { if Item Deleted }\end{array}$ & $\begin{array}{c}\text { Scale Variance if Item } \\
\text { Deleted }\end{array}$ & Item-Total Correlation & $\begin{array}{c}\text { Cronbach's Alpha } \\
\text { if Item Deleted }\end{array}$ \\
\hline P11 & 12.85 & 4.504 & .208 & .679 \\
P12 & 12.60 & 3.694 & .532 & .519 \\
P13 & 12.66 & 3.830 & .489 & .542 \\
P14 & 12.59 & 3.696 & .527 & .521 \\
P15 & 12.65 & 4.603 & .250 & .652 \\
\hline
\end{tabular}

Sumber: Data diolah oleh SPSS 16

Hasil uji validitas terhadap variabel $\mathrm{X}_{4}$ atau kualitas pelayanan fiskus adalah valid, karena r-hitung (Corrected Item-Total Correlation) $>$ r-tabel (0.17) untuk setiap pernyataan yang ada dalam kuesioner.

Tabel 6 Uji Validitas $\mathrm{X}_{4}$ (Kualitas Pelayanan Fiskus)

Item-Total Statistics

\begin{tabular}{rrrrr}
\hline & $\begin{array}{c}\text { Scale } \\
\text { Mean if Item } \\
\text { Deleted }\end{array}$ & $\begin{array}{c}\text { Scale } \\
\text { Variance if Item } \\
\text { Deleted }\end{array}$ & $\begin{array}{c}\text { Corrected } \\
\text { Item-Total } \\
\text { Correlation }\end{array}$ & $\begin{array}{c}\text { Cronbach's } \\
\text { Alpha if Item Deleted }\end{array}$ \\
\hline P16 & 12.74 & 3.667 & .521 & .478 \\
P17 & 12.63 & 3.950 & .319 & .587 \\
P18 & 12.71 & 4.210 & .269 & .610 \\
P19 & 12.51 & 4.538 & .284 & .597 \\
P20 & 12.76 & 3.634 & .465 & .503 \\
\hline
\end{tabular}

Sumber: Data diolah oleh SPSS 20 
Selanjutnya peneliti menguji variabel $Y$ atau kepatuhan Wajib Pajak. Hasil dari pengujian ini menunjukan bahwa pernyataan yang ada didalam kuesioner adalah valid. Hasil pengujian tersebut dijabarkan pada tabel berikut.

Tabel 7 Uji Validitas Y (Kepatuhan Wajib Pajak)

Item-Total Statistics

\begin{tabular}{lccrc}
\hline & $\begin{array}{c}\text { Scale } \\
\text { Mean if Item } \\
\text { Deleted }\end{array}$ & $\begin{array}{c}\text { Scale } \\
\text { Variance if Item } \\
\text { Deleted }\end{array}$ & $\begin{array}{c}\text { Corrected } \\
\text { Item-Total Correlation }\end{array}$ & $\begin{array}{c}\text { Cronbach's } \\
\text { Alpha if Item Deleted }\end{array}$ \\
\hline P21 & 12.40 & 5.364 & .227 & .654 \\
P22 & 12.47 & 4.318 & .433 & .565 \\
P23 & 12.55 & 4.228 & .414 & .576 \\
P24 & 12.57 & 4.183 & .500 & .530 \\
P25 & 12.53 & 4.735 & .389 & .588 \\
\hline \multicolumn{4}{c}{ Sumber: Data diolah oleh SPSS 20. }
\end{tabular}

\section{Uji Reliabilitas}

Uji reliabilitas dapat dilakukan dengan menghitung koefisien Cronbach's Alpha. Suatu kuesioner dikatakan reliable jika nilai Cronbach's Alpha lebih besar dari 0,6 atau 60\%. Berikut ini adalah hasil pengujian reliabilitas variabel $\mathrm{X}_{1}, \mathrm{X}_{2}, \mathrm{X}_{3}, \mathrm{X}_{4}$, dan $\mathrm{Y}$. Berikut adalah tabel hasil pengujian untuk keempat variabel bebas dan variabel terikat dalam penelitian ini yang menunjukkan bahwa keseluruhan pertanyaan yang mendukung setiap variabel bersifat reliable.

Tabel 8 Hasil Uji Reliabilitas $\mathrm{X}_{1}$ (Tingkat Kesadaran Membayar Pajak)

Reliability Statistics

\begin{tabular}{rrrr}
\hline Cronbach's Alpha & N of Items & \\
\hline & .711 & & 5 \\
\hline
\end{tabular}

Tabel 9 Hasil Uji Reliabilitas $X_{2}$ (Pemahaman Wajib Pajak Terhadap Manfaat Pajak) Reliability Statistics

\begin{tabular}{llll}
\hline Cronbach's Alpha & N of Items & 5 \\
\hline & .760 & & \\
\hline
\end{tabular}

Tabel 10 Hasil Uji Reliabilitas $X_{3}$ (Pemahaman Tentang Sanksi Pajak) Reliability Statistics

\begin{tabular}{lll}
\hline Cronbach's Alpha & N of Items \\
\hline & .642 & 5 \\
\hline
\end{tabular}

Tabel 11 Hasil Uji Reliabilitas $\mathrm{X}_{4}$ (Kualitas Pelayanan Fiskus) Reliability Statistics

\begin{tabular}{lll}
\hline Cronbach's Alpha & N of Items & \\
\hline & .613 & 5 \\
\hline
\end{tabular}


Tabel 12 Hasil Uji Reliabilitas Y (Kepatuhan Wajib Pajak)

Reliability Statistics

\begin{tabular}{rrr}
\hline Cronbach's Alpha & N of Items \\
\hline & .639 & 5 \\
\hline
\end{tabular}

\section{Uji Normalitas}

Uji normalitas untuk seluruh variabel ini berguna karena syarat untuk melakukan parametrictesting adalah data harus berdistribusi normal. Hasil uji normalitas untuk seluruh variabel ditunjukkan pada tabel berikut.

Tabel 13 Uji Normalitas $\mathrm{X}_{1}, \mathrm{X}_{2}, \mathrm{X}_{3}, \mathrm{X}_{4}$, dan $\mathrm{Y}$ One-Sample Kolmogorov-Smirnov Test

\begin{tabular}{|c|c|c|c|c|c|c|}
\hline \multirow[b]{2}{*}{$\mathrm{N}$} & & \multirow{2}{*}{$\begin{array}{l}\text { Tingkat_Kesad } \\
\text { aran_Membaya } \\
\text { r_Pajak } \\
92\end{array}$} & $\begin{array}{l}\text { Pemahaman_W } \\
\text { ajib_Pajak_Terh } \\
\text { adap_Manfaat_ } \\
\text { Pajak }\end{array}$ & \multirow{2}{*}{$\begin{array}{l}\text { Pemahaman_ } \\
\text { Tentang_Sank } \\
\text { si } \\
\quad 92\end{array}$} & \multirow{2}{*}{ 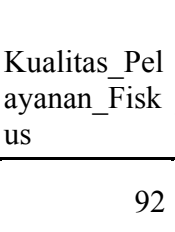 } & \multirow{2}{*}{ 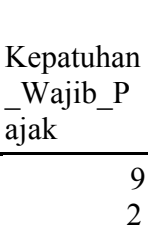 } \\
\hline & & & 92 & & & \\
\hline \multirow[t]{2}{*}{ Normal Parameters ${ }^{\mathrm{a}}$} & Mean & 15.34 & 15.78 & $\begin{array}{r}15.8 \\
4\end{array}$ & $\begin{array}{l}15 \\
.84\end{array}$ & $\begin{array}{r}1 \\
5.63\end{array}$ \\
\hline & $\begin{array}{l}\text { Std. } \\
\text { Deviation }\end{array}$ & 2.853 & 2.729 & $\begin{array}{r}2.41 \\
5\end{array}$ & $\begin{array}{r}2 . \\
387\end{array}$ & $\begin{array}{r}2 \\
.558\end{array}$ \\
\hline \multirow[t]{3}{*}{$\begin{array}{l}\text { Most Extreme } \\
\text { Differences }\end{array}$} & Absolute & .125 & .119 & .125 & $\begin{array}{r}.1 \\
25\end{array}$ & 123 \\
\hline & Positive & .055 & .061 & .062 & $\begin{array}{l}.0 \\
63\end{array}$ & $06 \dot{5}$ \\
\hline & Negative & -.125 & -.119 & .125 & .125 & .123 \\
\hline \multicolumn{2}{|c|}{ Kolmogorov-Smirnov Z } & 1.194 & 1.139 & $\begin{array}{r}1.19 \\
7\end{array}$ & $\begin{array}{r}1 . \\
199\end{array}$ & $\begin{array}{r}1 \\
.176\end{array}$ \\
\hline \multicolumn{2}{|c|}{ Asymp. Sig. (2-tailed) } & .115 & .150 & .114 & $\begin{array}{r}.1 \\
13\end{array}$ & $12 \dot{6}$ \\
\hline
\end{tabular}

a. Test distribution is Normal.

Data tersebut menunjukkan bahwa seluruh variabel yang digunakan dalam penelitian ini berdistribusi normal karena variabel $\mathrm{X}_{1}$ atau tingkat kesadaran membayar pajak $(0.115>0.05), \mathrm{X}_{2}$ atau pemahaman Wajib Pajak terhadap manfaat pajak $(0.150>0.05), X_{3}$ atau pemahaman tentang sanksi $(0.114>0.05), \mathrm{X}_{4}$ atau kualitas pelayanan fiskus $(0.113>0.05)$ dan $\mathrm{Y}$ atau kepatuhan wajib pajak $(0,126>0.05)$.

\section{Uji Heterokedastisitas}

Pada grafik scatterplot terlihat bahwa titik-titik menyebar secara acak serta tersebar baik di bagian atas angka nol atau di bagian bawah angka nol dari sumbu vertikal atau sumbu Y. Dengan demikian dapat disimpulkan bahwa tidak terjadi heteroskedastisitas dalam model regresi ini, sehingga layak dipakai untuk memprediksi kepatuhan Wajib Pajak berdasarkan variabel independen yaitu tingkat kesadaran membayar pajak, pemahaman Wajib Pajak terhadap manfaat pajak, pemahaman tentang sanksi pajak dan kualitas pelayanan fiskus. 


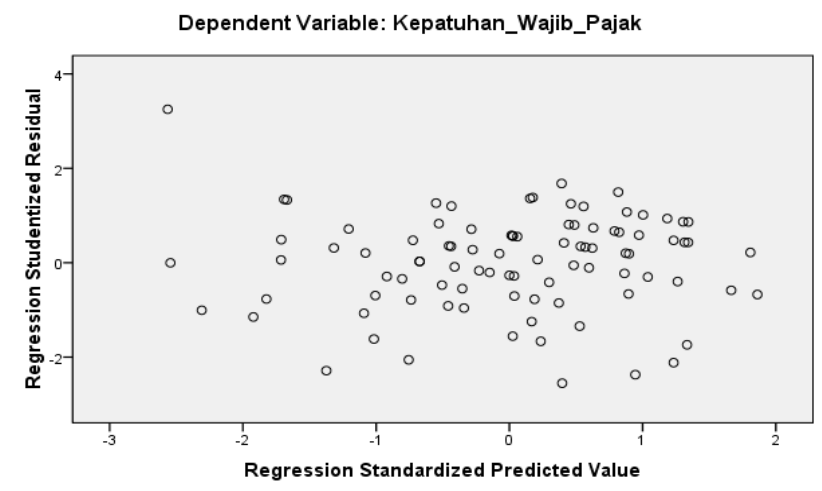

Gambar 1 Hasil Uji Heteroskedastisitas

\section{Uji Multikolearitas}

Berdasarkan tabel Coefficients ${ }^{\mathrm{a}}$ yang diperoleh pada Tabel 14, dapat diketahui bahwa nilai variabel $\mathrm{X}_{1}$ atau tingkat kesadaran membayar pajak sebesar $(1.002<10), \mathrm{X}_{2}$ atau pemahaman Wajib Pajak terhadap manfaat pajak $(1.112<10), X_{3}$ atau pemahaman tentang sanksi pajak $(1.073<10)$ dan $\mathrm{X}_{4}$ atau kualitas pelayanan fiskus $(1.083<10)$. Dengan demikian, dapat disimpulkan bahwa tidak terjadi gejala multikorelasi di antara variabel bebas.

Tabel 14 Hasil Uji Multikorelasi Coefficients $^{\mathrm{a}}$

\begin{tabular}{crrr}
\hline & & \multicolumn{2}{c}{ Collinearity Statistics } \\
\cline { 3 - 4 } Model & & Tolerance & VIF \\
\hline \multicolumn{2}{r}{ Tingkat_Kesadaran_Membayar_Pajak } & .998 & 1.002 \\
aat_Pajak Pemahaman_Wajib_Pajak_Terhadap_Manf & .899 & 1.112 \\
& Pemahaman_Tentang_Sanksi & .932 & 1.073 \\
& Kualitas_Pelayanan_Fiskus & .923 & 1.083 \\
\hline
\end{tabular}

a. Dependent Variable: Kepatuhan_Wajib_Pajak

\section{Uji Hipotesis}

\section{Pengujian Koefisien Determinasi $\left(\mathbf{R}^{2}\right)$}

Pengujian koefisien determinasi dilakukan untuk menentukan seberapa besar persentase dari masing-masing variabel, seperti variabel dependen dan variabel independen yang digunakan dalam model regresi linear berganda ini. Untuk mengetahui persentase analisis determinasi, berikut ini adalah keterangan yang harus diperhatikan dalam mengetahui presentase analisis determinasi: (a) jika nilai adjusted $\mathrm{R}^{2}=0$, berarti variabel-variabel independen tidak memiliki kemampuan untuk menjelaskan variabel-variabel dependen; (b) jika nilai adjusted $\mathrm{R}^{2}$ mendekati 1, berarti variabel-variabel independen dapat memberikan hampir seluruh informasi yang dibutuhkan untuk memprediksi variasi variabel dependen. Hasil pengujian koefisien determinasi dapat dilihat pada tabel berikut. 
Tabel 15 Hasil Uji Koefisien Determinasi Model Summary ${ }^{\mathrm{b}}$

\begin{tabular}{|c|c|c|c|c|c|}
\hline & & $R$ & Adjusted R & Std. Error & \\
\hline Model & $\mathrm{R}$ & Square & Square & of the Estimate & Durbin-Watson \\
\hline 1 & $\begin{array}{r}.4 \\
03^{\mathrm{a}}\end{array}$ & $\begin{array}{r}.16 \\
3\end{array}$ & .124 & 2.394 & 1.624 \\
\hline
\end{tabular}

a. Predictors: (Constant), Kualitas_Pelayanan_Fiskus, Tingkat_Kesadaran_Membayar_Pajak, Pemahaman_Tentang_Sanksi, Pemahaman_Wajib_Pajak_Terhadap_Manfaat_Pajak

b. Dependent Variable: Kepatuhan_Wajib_Pajak

Dari hasil uji tersebut, didapat nilai Adjusted R Square sebesar 0.124 atau $12.4 \%$. Hal ini menunjukkan bahwa $12.4 \%$ variabel kepatuhan Wajib Pajak dijelaskan oleh empat vatiabel independen, yaitu tingkat kesadaran membayar pajak, pemahaman Wajib Pajak terhadap manfaat pajak, pemahaman tentang sanksi pajak dan kualitas pelayanan fiskus. Sebesar (100\% - 12.4\%) 87.6\% dijelaskan oleh variabel independen lain.

\section{Pengujian Signifikansi Simultan (Uji Statistik F)}

Pengujian model penelitian akan dilakukan dengan uji $\mathrm{F}$ dengan tingkat signifikansi $5 \%$. Dalam uji F ini, hipotesis dapat dirumuskan sebagai berikut:

Ho : Tidak ada pengaruh antara variabel tingkat kesadaran membayar pajak, pemahaman Wajib Pajak terhadap manfaat pajak, pemahaman tentang sanksi pajak, dan kualitas pelayanan fiskus dengan ingkat kepatuhan Wajib Pajak yang ditentukan.

Ha : Ada pengaruh antara variabel tingkat kesadaran membayar pajak, pemahaman Wajib Pajak terhadap manfaat pajak, pemahaman tentang sanksi pajak, dan kualitas pelayanan fiskus dengan tingkat kepatuhan Wajib Pajak yang ditentukan.

Dasar pengambilan keputusan sebagai berikut: (a) jika p-value < 0.05, Ho ditolak (ada pengaruh); (b) jika $p$-value $>0.05$, Ho diterima (tidak ada pengaruh).

Hasil pengujian signifikansi simultan dapat dilihat pada tabel berikut ini.

Tabel 16 Hasil Uji Signifikansi Simultan

\begin{tabular}{|c|c|c|c|c|c|}
\hline \multicolumn{6}{|c|}{ ANOVA $^{\text {b }}$} \\
\hline Model & Sum of Squares & & & $\mathrm{F}$ & \\
\hline Regression & 96.936 & 4 & 24.234 & $\begin{array}{r}4 . \\
229\end{array}$ & $\begin{array}{r}.0 \\
04^{\mathrm{a}}\end{array}$ \\
\hline Residual & 498.499 & 87 & 5.730 & & \\
\hline Total & 595.435 & 91 & & & \\
\hline
\end{tabular}

a. Predictors: (Constant), Kualitas_Pelayanan_Fiskus, tingkat_Kesadaran_Membayar_Pajak, Pemahaman_Tentang_Sanksi, Pemahaman_Wajib_Pajak_Terhadap_Manfaat_Pajak

b. Dependent Variable: Kepatuhan_Wajib_Pajak

Berdasarkan hasil output tabel, didapatkan nilai $\mathrm{F}$ sebesar 4.229 pada nilai probabilitas (pvalue) yaitu 0.004 . Hal tersebut menunjukkan bahwa Ho ditolak karena nilai probabilitas signifikansi (p-value) sebesar $0.004<0.05$ atau $5 \%$ yang artinya secara simultan berpengaruh secara signifikan antara variabel tingkat kesadaran membayar pajak, pemahaman Wajib Pajak terhadap manfaat pajak, pemahaman tentang sanksi pajak, dan kualitas pelayanan fiskus dengan tingkat kepatuhan Wajib Pajak yang ditentukan. 


\section{Pengujian Signifikansi Parameter Individual (Uji Statistik t)}

Penelitian ini memiliki 4 variabel independen, yaitu $X_{1}$ atau tingkat kesadaran membayar pajak, $X_{2}$ atau pemahaman Wajib Pajak terhadap manfaat pajak, $X_{3}$ atau pemahaman tentang sanksi pajak, $\mathrm{X}_{4}$ atau kualitas pelayanan fiskus dan memiliki satu variabel dependen, yaitu kepatuhan Wajib Pajak (Y). Hipotesis yang diterapkan dalam pengujian hipotesis dengan menggunakan uji t adalah sebagai berikut:

Ho1 : Tidak ada pengaruh yang signifikan antara variabel kesadaran membayar pajak terhadap variabel kepatuhan Wajib Pajak.

Ha1 : Ada pengaruh yang signifikan antara variabel kesadaran membayar pajak terhadap kepatuhan Wajib Pajak.

Ho2 : Tidak ada pengaruh yang signifikan antara variabel pemahaman Wajib Pajak tentang manfaat pajak terhadap variabel kepatuhan Wajib Pajak.

Ha2 : Ada pengaruh yang signifikan antara variabel pemahaman Wajib Pajak tentang manfaat pajak terhadap kepatuhan Wajib Pajak.

Ho3 : Tidak ada pengaruh yang signifikan antara variabel Pemahaman sanksi pajak terhadap variabel kepatuhan Wajib Pajak.

Ha3 : Ada pengaruh yang signifikan antara variabel Pemahaman sanksi pajak terhadap variabel kepatuhan Wajib Pajak.

Ho4 : Tidak ada pengaruh yang signifikan antara variabel Kualitas Pelayanan Fiskus terhadap variabel kepatuhan Wajib Pajak.

Ha4 : Ada pengaruh yang signifikan antara variabel Kualitas Pelayanan Fiskus terhadap variabel kepatuhan Wajib Pajak.

Hasil uji t dapat dilihat pada tabel berikut.

Tabel 17 Hasil Uji Signifikansi Parameter Individual (Uji Statistik t)

Coefficients $^{\mathrm{a}}$

\begin{tabular}{|c|c|c|c|c|c|c|}
\hline \multirow[b]{2}{*}{ Model } & \multicolumn{3}{|c|}{ Unstandardized Coefficients } & $\begin{array}{l}\text { Standardized } \\
\text { Coefficients }\end{array}$ & & \multirow[b]{2}{*}{ t Sig. } \\
\hline & $\mathrm{B}$ & Std. Error & & Beta & & \\
\hline (Constant) & 8.183 & 2.676 & & & 3.058 & .003 \\
\hline $\begin{array}{l}\text { Tingkat_Kesadaran_Membayar_ } \\
\text { Pajak }\end{array}$ & .011 & & .088 & .012 & 2.120 & .905 \\
\hline $\begin{array}{l}\text { Pemahaman_Wajib_Pajak_Terha } \\
\text { dap_Manfaat_Pajak }\end{array}$ & -.004 & & .097 & -.005 & $5-.045$ & .964 \\
\hline Pemahaman_Tentang_Sanksi & .419 & & .108 & .395 & 3.888 & .000 \\
\hline Kualitas_Pelayanan_Fiskus & .046 & & .109 & .043 & 3.419 & .676 \\
\hline
\end{tabular}

a. Dependent Variable: Kepatuhan_Wajib_Pajak

Simpulan dari uji t di atas adalah sebagai berikut. 
Tabel 18 Rangkuman Uji Hipotesis

\begin{tabular}{|c|c|c|c|}
\hline Hipotesis & Pernyataan & Nilai & Keterangan \\
\hline Hol & $\begin{array}{l}\text { tidak terdapat pengaruh yang signifikan antara variabel } \\
\text { kesadaran membayar pajak terhadap variabel kepatuhan } \\
\text { Wajib Pajak. }\end{array}$ & 0.905 & $\begin{array}{l}\text { Ho1 diterima } \\
\text { Ha1 ditolak }\end{array}$ \\
\hline Ho2 & $\begin{array}{l}\text { tidak terdapat pengaruh yang signifikan antara variabel } \\
\text { pemahaman Wajib Pajak tentang manfaat pajak terhadap } \\
\text { variabel kepatuhan Wajib Pajak. }\end{array}$ & 0.964 & $\begin{array}{l}\text { Ho2 diterima } \\
\text { Ha2 ditolak }\end{array}$ \\
\hline Ha3 & $\begin{array}{l}\text { ada pengaruh yang signifikan antara variabel pemahaman } \\
\text { sanksi pajak terhadap variabel kepatuhan Wajib Pajak. }\end{array}$ & 0.000 & $\begin{array}{l}\text { Ho3 ditolak } \\
\text { Ha3 diterima }\end{array}$ \\
\hline Ho4 & $\begin{array}{l}\text { tidak terdapat pengaruh yang signifikan antara variabel } \\
\text { kualitas pelayanan fiskus terhadap variabel kepatuhan Wajib } \\
\text { Pajak. }\end{array}$ & 0.676 & $\begin{array}{l}\text { Ho4 diterima } \\
\text { Ha4 ditolak }\end{array}$ \\
\hline
\end{tabular}

\section{Analisis Regresi Linear Berganda}

Dari tabel dapat diketahui persamaan regresi untuk tingkat kesadaran membayar pajak, pemahaman tentang manfaat pajak, pemahaman tentang sanksi pajak dan kualitas pelayanan fiskus terhadap kepatuhan Wajib Pajak Orang Pribadi sebagai berikut:

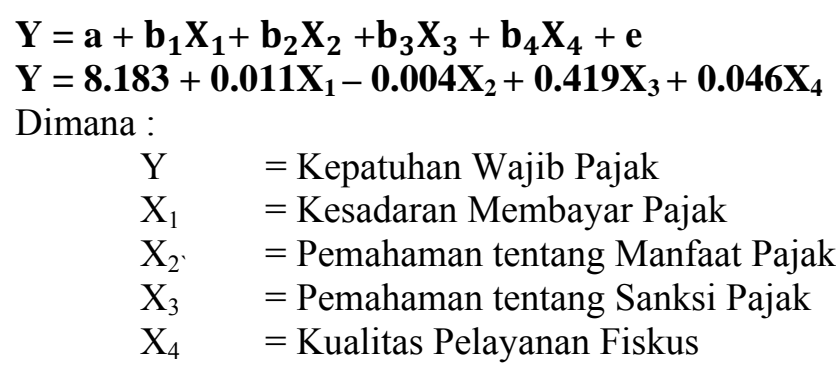

Pada model regresi ini, nilai konstanta sebesar 8.183 yang berarti jika tidak ada kenaikkan dari variabel $X_{1}, X_{2}, X_{3}$ dan $X_{4},\left(X_{1}, X_{2}, X_{3}, X_{4}=0\right)$ maka nilai variabel $Y$ adalah sebesar 8.183 satuan. Jika variabel $\mathrm{X}_{1}$ naik 1 satuan dan variabel $\mathrm{X}_{2}, \mathrm{X}_{3}$ dan $\mathrm{X}_{4}$ adalah 0 (nol) akan memberikan kenaikan sebesar 0.011 terhadap nilai $Y$. Kenaikan tersebut tidak signifikan karena nilai Sig. Dari variabel $\mathrm{X}_{1}$ lebih besar dari $0.05(0.905>0,05)$. Jika variabel $\mathrm{X}_{2}$ naik 1 satuan dan variabel $\mathrm{X}_{1}, \mathrm{X}_{3}$ dan $\mathrm{X}_{4}$ adalah 0 (nol) memberikan penuruan sebesar 0.004 terhadap nilai Y. Penurunan tersebut tidak signifikan karena nilai Sig. Dari variabel $\mathrm{X}_{2}$ lebih besar dari 0.05. (0.964>0.05). Jika variabel $\mathrm{X}_{3}$ naik 1 satuan dan variabel $\mathrm{X}_{1}, \mathrm{X}_{2}$ dan $\mathrm{X}_{4}$ adalah 0 (nol) akan memberikan kenaikan sebesar 0.419 terhadap nilai $\mathrm{Y}$. Kenaikan tersebut akan berpengaruh secara signifikan terhadap variabel $\mathrm{Y}$ karena nilai Sig. Dari variabel $\mathrm{X}_{3}$ lebih kecil dari pada $0.05(0.000<0.05)$. Jika variabel $\mathrm{X}_{4}$ naik 1 satuan dan variabel $\mathrm{X}_{1}$, $\mathrm{X}_{2}, \mathrm{X}_{3}$ adalah 0 (nol) akan memberikan kenaikan sebesar 0.046 terhadap nilai Y. Kenaikan tersebut tidak signifikan karena nilai Sig. Dari variabel $\mathrm{X}_{4}$ lebih besar dari $0.05(0.676>0,05)$.

\section{SIMPULAN}

Berdasarkan pembahasan dan analisis, maka dapat diambil simpulan sebagai berikut. Pertama, pengujian hipotesis untuk menganalisis apakah kesadaran membayar pajak berpengaruh terhadap kepatuhan Wajib Pajak Orang Pribadi dalam memenuhi kewajiban perpajakan di KPP Tigaraksa Tangerang menunjukkan hasil tidak terdapat pengaruh yang signifikan antara variabel kesadaran membayar pajak terhadap kepatuhan Wajib Pajak Orang Pribadi. Kedua, pengujian hipotesis untuk 
menganalisis apakah pemahaman tentang manfaat pajak berpengaruh terhadap kepatuhan Wajib Pajak Orang Pribadi dalam memenuhi kewajiban perpajakan di KPP Tigaraksa Tangerang menunjukkan hasil tidak terdapat pengaruh yang signifikan antara variabel pemahaman Wajib Pajak tentang manfaat pajak terhadap variabel kepatuhan Wajib Pajak. Ketiga, pengujian hipotesis untuk menganalisis apakah pemahaman tentang sanksi pajak berpengaruh terhadap kepatuhan Wajib Pajak Orang Pribadi dalam memenuhi kewajiban perpajakan di KPP Tigaraksa Tangerang menunjukkan hasil ada pengaruh yang signifikan antara variabel pemahaman sanksi pajak terhadap variabel kepatuhan Wajib Pajak. Keempat, pengujian hipotesis untuk menganalisis apakah kualitas pelayanan fiskus berpengaruh terhadap kepatuhan Wajib Pajak Orang Pribadi dalam memenuhi kewajiban perpajakan di KPP Tigaraksa Tangerang menunjukkan hasil tidak terdapat pengaruh yang signifikan antara variabel kualitas pelayanan fiskus terhadap variabel kepatuhan Wajib Pajak. Kelima, pengujian signifikansi simultan (Uji Statistik F) untuk menganalisis apakah variabel tingkat kesadaran membayar pajak, pemahaman Wajib Pajak terhadap manfaat pajak, pemahaman tentang sanksi pajak, dan kualitas pelayanan fiskus secara bersama-sama berpengaruh terhadap tingkat kepatuhan Wajib Pajak menunjukkan hasil terdapat pengaruh secara bersama-sama terhadap kepatuhan Wajib Pajak.

\section{Saran}

Melihat hasil penelitian, maka yang harus dilakukan oleh fiskus untuk mendorong masyarakat pemilik NPWP melakukan kewajiban melaporkan dan menyetorkan pajak terutang harus difokuskan pada pembenahan peraturan perundang-undangan, mengingat masyarakat Indonesia yang lebih memerhatikan sanksi yang berlaku dibandingkan dengan faktor-faktor lain. Artinya, Wajib Pajak lebih cenderung membutuhkan payung peraturan pajak yang dapat memberikan jaminan hukum kepada mereka untuk mendorong mereka melakukan kewajiban pajaknya. Namun untuk mendorong profesionalitas fiskus, faktor-faktor lain seperti pelayanan di kantor pajak, pemberian sosialisasi pajak kepada Wajib Pajak mengenai hak dan kewajiban tetap harus dijalankan.

\section{DAFTAR PUSTAKA}

BPS. (n.d.). Realisasi Penerimaan Negara (Milyar Rupiah), 2007-2014. Diakses dari http://www.bps.go.id/tab_sub/view.php?tabel=1\&daftar=1\&id_subyek=13

Hasan. (2013, 18 November). Slogan Merakyat, Pajak Meningkat. Diakses dari http://www.pajak.go.id/content/article/slogan-merakyat-pajak-meningkat

Hidayat, W., dan Nugroho, A. A. (2010). Studi empiris Theory of Planned Behavior dan pengaruh kewajiban moral pada perilaku ketidakpatuhan pajak wajib pajak orang pribadi. Jurnal Akuntansi dan Keuangan, 12(2).

Peraturan Menteri Keuangan Republik Indonesia Nomor 192/PMK.03/2007 pasal 1. http://www.ortax.org/ortax/?mod=aturan\&page=show\&id=13038. Diunduh 27 Desember 2013.

Permadi, T., Nasir, A., dan Anisma, Y. (2013). Studi kemauan membayar pajak pada wajib pajak orang pribadi yang melakukan pekerjaan bebas (kasus pada KPP Pratama Tampan Pekanbaru). Jurnal Ekonomi, 21(2), 1-18. Diakses 14 Januari 2014 dari http://ejournal.unri.ac.id/index.php/JE/article/view/1750/1722

Resmi, S. (2011). Perpajakan: Teori dan Kasus. Buku 1 Edisi 6. Jakarta: Salemba Empat. 